AGRICULTURE AND BIOLOGY JOURNAL OF NORTH AMERICA

ISSN Print: 2151-7517, ISSN Online: 2151-7525, doi:10.5251/abjna.2012.3.10.406.412

(C) 2012, ScienceHu $\beta$, http://www.scihub.org/ABJNA

\title{
Development of immunological and molecular test systems for identification and typification of equine influenza virus
}

\author{
Matveyeva Valentina Mikhailovna, Koshemetov Zhumagali Kaukarbayevich, Sansyzbay \\ Abylay Rysbayevich, Koryagina Marina Ivanovna, Seisenbayeva Madina Sagadatovna, \\ Sandybayev Nurlan Tamambayevich
}

\author{
RGE "Research Institute for Biological Safety Problems" ME\&S Science Committee of \\ Republic of Kazakhstan; Gvardeiskiy, Kordaiskiy rayon, Zhambylskaya oblast, Republic \\ of Kazakhstan
}

\begin{abstract}
A competitive version of enzyme-linked immunosorbent assay (ELISA) based on usage of antibodies and conjugates to ribonucleoprotein (RNP) for screening of antibodies to certain subtypes of equine influenza virus has been developed as well as reverse transcription polymerase chain reaction (RT-PCR) for identification and typification of equine influenza virus, subtype $\mathrm{H}_{3}$, in biological materials.
\end{abstract}

Key words: enzyme-linked immunosorbent assay, polymerase chain reaction, ribonucleoprotein, conjugate, primer, antigen, serum

\section{INTRODUCTION}

Influenza infection is still a grand problem in horse breeding being a reason of large outbreaks of respiratory diseases among horses all over the world. It causes substantial damage to horse breeding owing to reduced breeding and sporting worth of convalescent animals, treatment costs, quarantine measures, displacement of sporting events schedule, and so on (Gendon, 1998; Thompson 2003).

Rapid spread and high mutability of the equine influenza agent impacts horse breeding negatively worldwide. It had been demonstrated during years 2007-2008 when horses in Russia, China, Mongolia, as well as in India, Japan and Australia were infected (Virmani et al., 2008; Yamanaka et al., 2008; Sakoda and Kida, 2007).

Currently the equine influenza is considered to be a transboundary disease and therefore the disease situation in adjacent countries is important for Kazakhstan. So, the development of up-to-date hightech test systems for rapid diagnosis of this infection is needed for efficient control of its spread. Among existing methods of laboratory diagnosis ELISA is one of available, high sensitive, specific and reliable methods to diagnose many viral diseases (Ballad and Zorikhina, 1983; Zhemayeva et al., 2009).
The advantages of polymerase chain reaction (PCR) are high specificity, sensitivity, universality of the procedure, simple and ease performance, possibility to detect several pathogens at once in one tube provided there are several pairs of appropriate primers in the reaction mixture, minimal contact with the infectious material, rapid results. PCR method allows working with any original pathology material without pure agent isolation (Fouchier et al., 2000; Sandybayev et al., 2007; Tudor, 2009).

The objective of the research was to develop diagnostic test systems on the basis of ELISA and RT-PCR for identification and typification of the equine influenza virus.

\section{MATERIALS AND METHODS}

Virus. In the study strains $\mathrm{A} /$ horse/Otar/764/07 $\left(\mathrm{H}_{3} \mathrm{~N}_{8}\right)$ and $\mathrm{A} /$ horse $1 /$ Kirgiziya/74 $\left(\mathrm{H}_{7} \mathrm{~N}_{7}\right)$ of equine influenza virus (EIV) were used. EIV was grown in embryonated chicken eggs (ECEs) following the fixed regulations (Abduraimov et al., 2011).

The collected virus-containing allantoic fluid (VAF) was assayed for a hemagglutinating agent in microhemagglutination test (HAT) with $0.5 \%$ suspension of rooster red blood cells. The test was performed following the conventional procedure (OIE, Manual of Standards..., 2004). 
Infectious and hemagglutinating activity of the virus was respectively $7.0-7.5 \mathrm{lg} \mathrm{EID}_{50} / \mathrm{cm}^{3}$ and $1: 512$ 1:1024.

Animals. Goats of local breed aged under one year were donors of specific antibodies.

Antigens. For immunization of goats EIV ribonucleoprotein (RNP) isolated from the concentrated and purified virus preparations were used.

Virus purification. Virus-containing allantoic fluid (VAF) was clarified by centrifugation at $785 \mathrm{~g}$, treated with antibiotics in dose $1000-2000 \mathrm{U} / \mathrm{ml}$. After that the suspension was supplemented with PEG-6000 to the final concentration $7 \%, \mathrm{pH}$ of the suspension was adjusted up to 8.5. Sedimentation of the virus was performed for $24 \mathrm{~h}$ at $4^{\circ} \mathrm{C}$. Further on the virus sediment was concentrated by centrifugation at 5000 $\mathrm{g}$ for $1.5 \mathrm{~h}$. Then the virus was ultracentrifuged at $106000 \mathrm{~g}$ for $1.5 \mathrm{~h}$. The virus sediment was homogenized and clarified at $5000 \mathrm{~g}$ for $10 \mathrm{~min}$. Activity of the isolated virus was evaluated in HAT. Afterwards the virus was purified in sucrose density gradient (20-60\%). The purified virus was resuspended in a 100-fold volume of the sterile $0.05 \mathrm{M}$ phosphate buffer solution (PBS), $\mathrm{pH}$ 7.2-7.4. Protein concentration and hemagglutinating activity in the purified virus preparation was determined.

EIV ribonucleoprotein isolation. The virus was treated with the bromelain enzyme for $24 \mathrm{~h}$ at $37^{\circ} \mathrm{C}$ and at a virus-enzyme ratio 9:1, the enzyme concentration being $13 \mathrm{mg} / \mathrm{ml}$. After that the virus was sedimented at $106000 \mathrm{~g}$ for $90 \mathrm{~min}$ and resuspended in $0.05 \mathrm{M}$ PBS (4-fold greater volume than the original one). The virus was destroyed by Tween-ether treatment. Thereto the virus suspension was supplemented with $0.1 \%$ Tween- 80 and kept at low temperature for $30 \mathrm{~min}$ with occasional stirring. After that the virus and cold ether were mixed at a ratio $1: 1$ and kept at $4^{\circ} \mathrm{C}$ for two hours under continuous agitation. The bottom weakly opalescent water phase was withdrawn and the ether remains were ventilated at $4^{\circ} \mathrm{C}$ for $24 \mathrm{~h}$. The material was clarified by centrifugation at $3000 \mathrm{rpm}$. The nondisrupted virions were sedimented at $22000 \mathrm{rpm}$ for $30 \mathrm{~min}$, and then the supernatant was ultracentrifuged at $45000 \mathrm{rpm}$ for $2 \mathrm{~h}$ for RNP isolation. The purified RNP preparation was assayed in HAT and solid-phase ELISA, its concentration was also determined.

Raising antisera to EIV ribonucleoprotein. Donors of specific antibodies against EIV ribonucleoprotein were goats of local breed under one year. The purified RNP preparation was fourfold injected intramuscularly in the area of prescapular lymph nodes in increasing doses $(100,300,600$ and 600 $\mu \mathrm{g} / \mathrm{ml})$ at the interval of 14 days. The second administration was performed in complex with $0.05 \%$ aluminium hydroxide. In 14 days after the last injection of RNP blood sera were taken from the goats and assayed for antibodies to EIV ribonucleoprotein in serological tests (diffusion precipitation test and indirect ELISA).

Protein content was determined according to Lowry et al. (1951) with bovine serum albumin (BSA) produced by "Sigma" (USA) as a standard.

Test system Directigen Flu A. The reaction was performed following the directions of the manufacturer of the test system.

Immunoglobulins to EIV ribonucleoprotein were extracted from specific antisera by Kohn's alcohol method (Frimel, 1987).

Conjugates were prepared according to Wilson and Nakane (1978) with use of horseradish peroxidase, type VI-A, produced by "Sigma" (USA).

RNA extraction from the purified virus preparations was carried out with use of QIAamp® Viral RNA Mini Kit produced by QIAGEN (USA) following the instructions of the manufacturer.

Search and analysis of EIV nucleotide sequences. EIV nucleotide sequences were searched on the site $\mathrm{NCBI}$ - Influenza Virus Resource (Information, Search and Analysis).

Analysis and multiple nucleotide sequence alignment were conducted with the help of the application packages "Fast PCR" and "Bio Edit".

Selection of primers. Oligonucleotide primers to be used in EIV detection and typification of HA gene were selected with the help of the on-line program "Primer3" as well as application "Primer Expressv2.0". The primers were characterized by using program "Oligo Analyses".

Polymerase chain reaction (PCR) was performed in an amplifier "Mastercycler ep gradientS" (Eppendorf, Germany) that provides regular cooling and heating of the tubes accurate to at least $0.1^{\circ} \mathrm{C}$.

Reverse transcription was carried out with use of "Oligo (dT) ${ }_{18} "(50 \mu \mathrm{M})$ and directly cDNAs of virus genes were amplified with use of the selected primers. 
Amplification products were assessed by electrophoresis in $2.0 \%$ agarose gel. Markers of molecular weights SERVA DNA Standard pBR 328 Mix (Germany) were used.

\section{RESULTS AND DISCUSSION}

Usually for serological detection of influenza virus hemagglutination inhibition and microneutralization tests are used as well as various ELISA methods (Sominina et al., 2009; Tsivanyuk et al., 2006).

Currently test systems for indirect ELISA are mainly used with species specific conjugates to detect antibodies against influenza viruses (Tsivanyuk et al., 2007). The test system described in our work allows detecting antibodies against EIV in blood sera of various animal species infected with this virus. Ribonucleoprotein was used as an antibody detecting antigen because according to the published data it is the most conservative protein for all 16 subtypes of influenza A virus (Zhemayeva et al., 2009).

For RNP isolation from the purified EIV preparations an optimal procedure with use of bromelain enzyme, virus disruption with Tween-ether followed by twofold separating ultracentrifugation of nondisrupted virions and RNP. The purified RNP preparation was assayed in HAT and ELISA, the protein concentration was also measured. Activity of the purified RNP preparations was $1 / 320 \div 1 / 640$ in ELISA and $1 / 4 \div 1 / 8$ in HAT, the protein concentration was $350 \div 385$ $\mu \mathrm{g} / \mathrm{cm}^{3}$.

Specificity of the purified RNP preparations was confirmed with the help of Directigen Flu A test system produced by "Becton Dickinson" (USA).

According to publications the influenza virus specific sera are mainly raised in rats and rabbits (Chomel et al., 1989; Petrov and Khaitov, 1984).

In our study we produced the specific sera against the EIV, type A, ribonucleoprotein in goats of local breeds since the WHO Expert Committee acknowledged the antisera raised in animals of this species giving minimal nonspecific reactions.

Goat antisera against EIV ribonucleoprotein were active up to dilution $1 / 8 \div 1 / 16$ in diffusion precipitation test, and up to $1 / 10240 \div 1 / 20480$ in ELISA.

Sensitivity, specificity and reproducibility of ELISA directly depend on quality of antibody-enzyme conjugates. Quality of conjugates in its turn depends on activity, specificity and purity of immunoglobulins $(\lg G)$ or antibodies used in conjugation.
IgG was isolated from active and EIV ribonucleoprotein specific antisera by 3-step sedimentation of albumin and IgG with ethanol in various concentrations according to Kohn.

The isolated IgG demonstrated activity and specificity comparable with activity and specificity of the original serum in the diffusion precipitation test and in ELISA. On the basis of the isolated immunoglobulin to RNP an immunoperoxidase conjugate with ultimate activity in ELISA as high as $1 / 800$ has been prepared from EIV stain A/horse/Otar/764/07 $\left(\mathrm{H}_{3} \mathrm{~N}_{8}\right)$ that is epizootically important for Kazakhstan.

A competitive variant of ELISA (c-ELISA) for detection of antibodies against EIV in blood sera of various animal species was developed on the basis of the prepared antigen (ribonucleoprotein) preparations and RNP- antibodies conjugated with horseradish peroxidase.

In the course of optimization of c-ELISA conditions for detection of type specific antibodies against EIV via chessboard titration an optimal sensitizing dose of the antigen and an optimal working dose of the conjugate to RNP was determined. Optimal concentration of the antigen for sensitization of the plate wells is $15-20 \mu \mathrm{g} / \mathrm{cm}^{3}$, and optimal dilution of the conjugate is $1: 100$.

Also temperature-time conditions for contact between immunoreagents were optimized and optimal saline solutions for their dilution in ELISA were selected.

The developed variant of c-ELISA was applied to detect type specific antibodies against EIV in blood sera from various animal species Nos. 1-12 (Figure 1) in 21 days after their experimental infection with virulent strains $\mathrm{A} /$ horse 1/Kirgiziya/74 $\left(\mathrm{H}_{7} \mathrm{~N}_{7}\right)$ and A/horse/Otar/ 764/07 $\left(\mathrm{H}_{3} \mathrm{~N}_{8}\right)$ in dose $4.0 \mathrm{lg}$ $\mathrm{TCD}_{50} / \mathrm{cm}^{3}$. The results of the performed studies are shown on Figure 1.

The results of sera in c-ELISA were compared with the results of their assaying in hemagglutination inhibition tests.

Figure 1 shows that the antibody titers in the tested sera from various animal species after their infection with EIV and in the diagnostic positive sera (Nos. 19, 20) in c-ELISA are comparable with the titers in HAIT, and in some cases exceed them, like, for instance, in testing specific (diagnostic) sera. Our data agree with the findings of Selleck P. et al. (2008) that show c-ELISA to be more sensitive than immunodiffusion and present the results comparable with HAIT. 

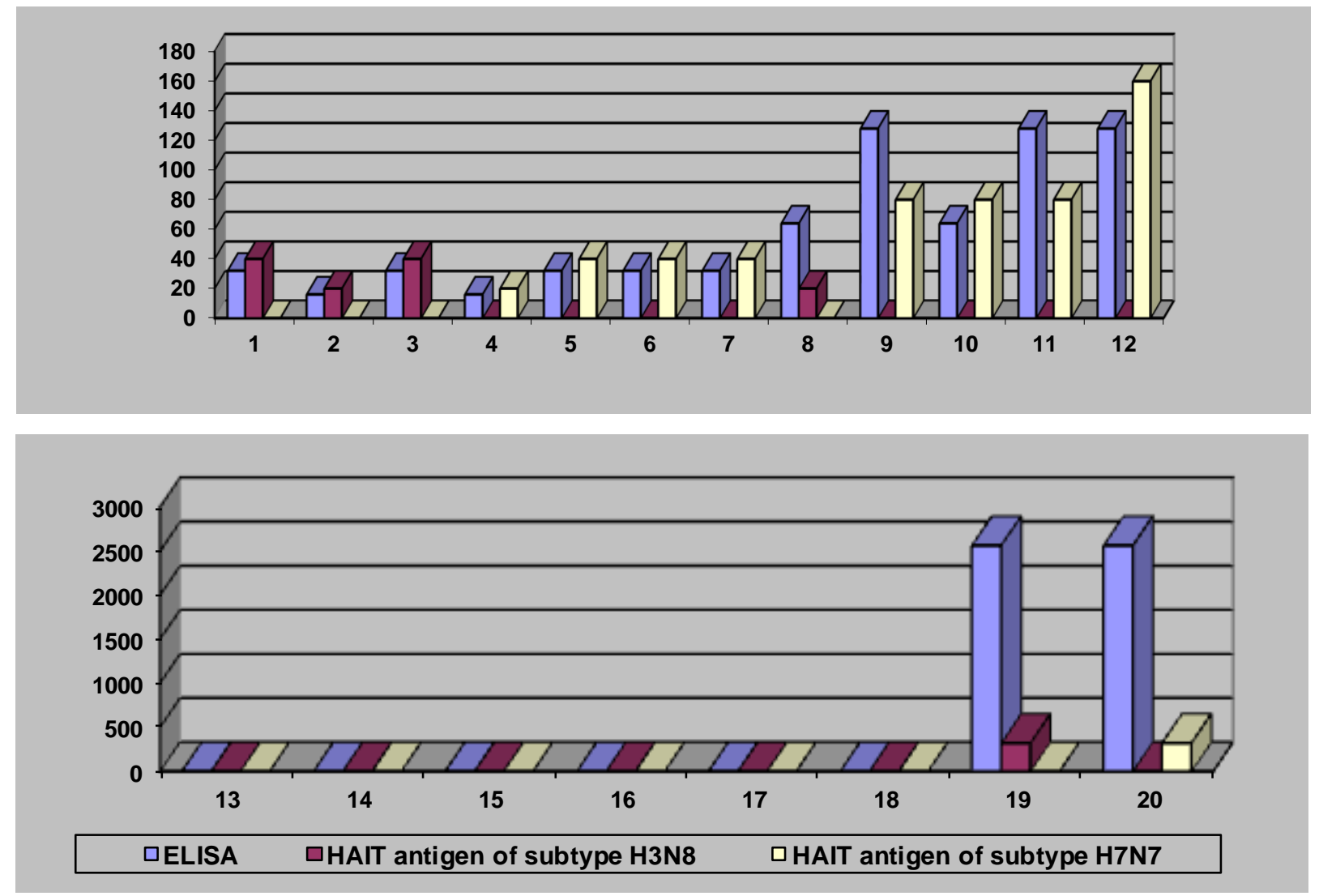

1. Positive serum from a stallion

2. Positive serum from mare No. 1

3. Positive serum from mare No. 2

4. Positive serum from a donkey

5. Positive serum from rabbit No. 1

6. Positive serum from rabbit No. 2

7. Positive serum from rabbit No. 3

8. Positive serum from guinea pig No. 1

9. Positive serum from guinea pig No. 2

10. Positive serum from guinea pig No. 3
11. Positive serum from guinea pig No. 4

12. Positive serum from guinea pig No. 5

13. Negative serum from a horse

14. Negative serum from a donkey

15. Negative serum from a rabbit

16. Negative serum from a guinea pig

17. Positive serum of Newcastle disease

18. Positive serum of equine infectious anemia

19. Positive serum to strain A/horse/Otar/ 764/07 $\left(\mathrm{H}_{3} \mathrm{~N}_{8}\right)$

20. Positive serum to strain $A$ /horse $1 /$ Kirgiziya/74 $\left(\mathrm{H}_{7} \mathrm{~N}_{7}\right)$

Fig 1 - Comparative activity of c-ELISA and HAIT in detection of antibodies against EIV in blood sera of various experimentally infected animal species.

So, we have developed a test system on the principle of competitive ELISA where EIV ribonucleoprotein is used as an antibody-detecting antigen since it is the most conservative protein in all 16 subtypes of influenza $A$ virus. The test system enables specific detection of antibodies against RNP of known EIV subtypes in blood sera of various animal species.

As it is well known many EIV strains recently isolated in different European and Asian countries belong to the second subtype $\mathrm{H}_{3} \mathrm{~N}_{8}$ (Bryant, 2011) and EIV of the first subtype $\left(\mathrm{H}_{7} \mathrm{~N}_{7}\right)$ circulates as a rule subclinically. Hence, we developed a diagnostic test system based on RT-PCR for identification of EIV, subtype $\mathrm{H}_{3} \mathrm{~N}_{8}$.

Effectiveness of the PCR method and its specificity depends on many parameters including buffer composition of a reaction mixture, temperature/time conditions, specificity and sensitivity of the chosen primers. However, correct primer selection, its localization on the DNA or RNA under study is the most critical step in development of a PCR method that particularly affects its specificity. 
For EIV $\left(\mathrm{H}_{3} \mathrm{~N}_{8}\right)$ identification by PCR we chose EIV hemagglutinin gene (HA-gene) as a target. Search in the Genbank database showed availability of 2993 complete nucleotide sequences (np) of this EIV gene. Multiple alignment of HA-gene sequences has made it possible to find out that its homology between types A, B and C is $24-39 \%$. Inside type A it is $91-100 \%$, and that is an evidence of high variability of the gene between the types of influenza virus and its conservatism inside type $A$. It enables to prepare primers and probes that will be specific to the conservative sequence of the EIV, type A, HA-gene and at the same time will not overlap the HA-gene sequences of other influenza virus types. In the result of oligonucleotide selection over 20 pairs of primers to the region of EIV HA-gene were generated. Absence of homology with other viruses of Orthomyxoviridae family and with other subtypes of influenza A virus was a principal criterion in oligonucleotide selection.

After preliminary selection for EIV, subtype $\mathrm{H}_{3}$, only two pairs of primers were chosen because they were highly conservative and specific to their subtype and were not homologous to other subtypes of influenza $A$ virus and to other cognate viruses and alongside they were suitable for RT-PCR procedure. The nucleotide sequences and their major characteristics are given in Table 1.

Table 1. Major characteristics of specific primers to be used in RT-PCR for equine influenza

\begin{tabular}{|c|c|c|c|c|}
\hline Nos. & Sequence $\left(5^{\prime}-3^{\prime}\right)$ & Position in genome & $\mathrm{Tm},{ }^{\circ} \mathrm{C}$ & GC,\% \\
\hline \multicolumn{5}{|c|}{ Primers to HA-gene of EIV, type $\mathrm{H}_{3}$} \\
\hline \multirow{2}{*}{1} & GCATCTCCAACGACAAGCCAT & 905 & 61.0 & 52.0 \\
\hline & ATCGGAACCCATACCACCCAT & 1108 & 61.0 & 52.0 \\
\hline \multirow{2}{*}{2} & AATGCTAGGAGACCCCCACTGT & 252 & 60.0 & 55.0 \\
\hline & GGCTCCACTTCTTCCGTTTTTG & 459 & 60.0 & 52.0 \\
\hline
\end{tabular}

The performed experiments resulted in choice of pair of primers $\mathrm{H} 3 / 252 \mathrm{~F}$ and $\mathrm{H} 3 / 459 \mathrm{R}$ that enables to generate a PCR-product of $207 \mathrm{np}$ in length.

This pair of primers was used in the assays with the objective to optimize the RT-PCR conditions. The results of the study have shown $55^{\circ} \mathrm{C}$ to be the optimal annealing temperature for the chosen primers.

\section{Table 2. Composition of the reaction mixture for PCR procedure}

\begin{tabular}{|l|c|c|c|}
\hline \multicolumn{1}{|c|}{ Composition of the reaction mixture } & Concentration & Stock & $50 \mu \mathrm{l} / \mathrm{sample}$ \\
\hline Buffer $(200 \mathrm{mM}$ Tris-HCL, pH 8.4, 500 mM KCL, 25 mM MgCL 2$)$ & $1 \mathrm{x}$ & $10 \mathrm{x}$ & 5 \\
\hline dNTP's (10 mM each dATP, dCTP, dGTP, dTTP) & $0.2 \mathrm{mM}$ & $10 \mathrm{mM}$ & 1 \\
\hline Forward Primer 1 (10 pM) & $0.1 \mu \mathrm{M}$ & $10 \mu \mathrm{M}$ & 2 \\
\hline Reverse Primer 2 $(10 \mathrm{pM})$ & $0.1 \mu \mathrm{M}$ & $10 \mu \mathrm{M}$ & 2 \\
\hline Tag-polymerase $(5000 \mathrm{units} / \mathrm{ml})$ & $0.05 \mathrm{u} / \mu \mathrm{l}$ & $5 \mathrm{u} / \mu \mathrm{l}$ & 1 \\
\hline CDNA & $\mathrm{x}$ & $\mathrm{x}$ & 1 \\
\hline DEPC-treated $\mathrm{H}_{2} \mathrm{O}$ & & $\mathrm{mQ}$ & 38 \\
\hline
\end{tabular}

The control RNA sample certified for influenza A viruses was used as a positive control.

The PCR product was analyzed in $2 \%$ agarose gel in the presence of ethidium bromide. $10 \mu \mathrm{l}$ of the tested material was applied into each gel well. The electrophoresis was carried out directly in TBE buffer. Availability of cDNA fragments sized $207 \mathrm{np}$ in the
Further experiments towards matching the composition of the reaction mixture and primers concentration for PCR performance were carried out. The optimal concentration of the reaction mixture and of primers for PCR was determined as a result. Optimal composition of the reaction mixture for PCR procedure is shown in Table 2. assayed sample is an evidence of the presence of RNA of EIV, subtype $\mathrm{H}_{3}$, in the original material.

Results of the electrophoretic separation of the PCR products for detection of the equine influenza virus, subtype $\mathrm{H}_{3}$, in the samples under study are shown on Figure 2. 


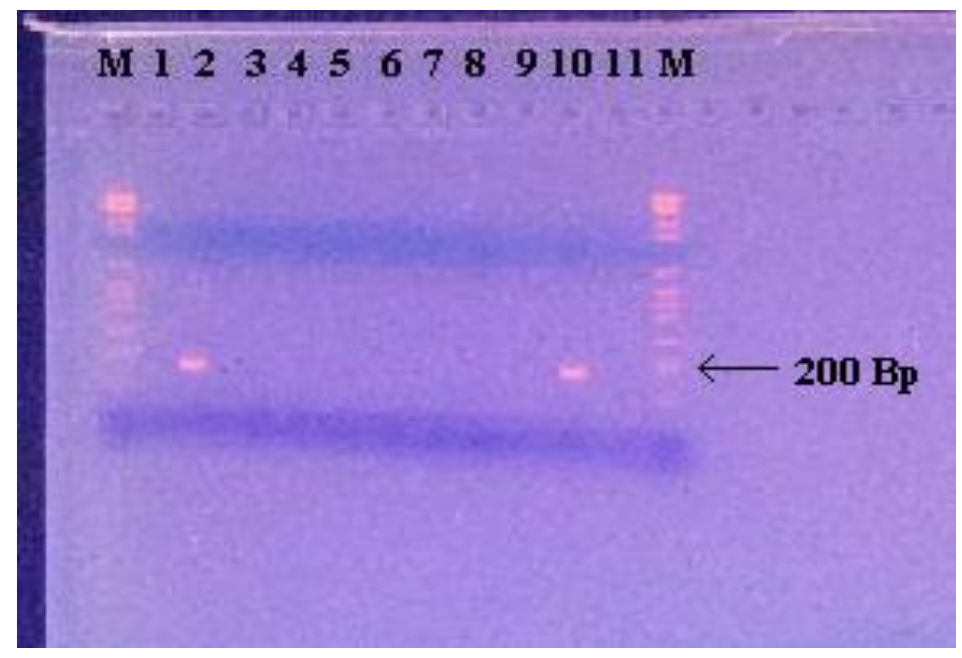

Fig 2 - M - molecular weight marker; 1 - negative control (water); 2 - positive control (standard EIV, strain A/horse/Miami/1/63); 3 - RNA of strain A/domestic goose/Pavlodar/1/05( $\left.\mathrm{H}_{5} \mathrm{~N}_{1}\right) ; 4$ - RNA of strain A/chicken/Rostok/29 $\left(\mathrm{H}_{7} \mathrm{~N}_{1}\right) ; 5$ - RNA of strain A/tern/South Africa/61 $\mathrm{H}_{5} \mathrm{~N}_{3} ; 6$ - RNA of strain A/horse 1/Kirgiziya/74 $\left(\mathrm{H}_{7} \mathrm{~N}_{7}\right) ; 7$ - RNA of strain A/Turkey/Massachusetts/3740/65 $\left(\mathrm{H}_{6} \mathrm{~N}_{2}\right) ; 8$ - RNA of strain A/Astana/818/09 $\left(\mathrm{H}_{1} \mathrm{~N}_{1}\right) ; 9-\mathrm{RNA}$ of strain A/horse 1/Kirgiziya/74 $\left(\mathrm{H}_{7} \mathrm{~N}_{7}\right) ; 10$ - saliva of a sick horse (EIV, subtype $\left.\mathrm{H}_{3} \mathrm{~N}_{8}\right) ; 11$ - RNA of the Newcastle disease virus.

Figure 2 shows that the developed RT-PCR has detected all positive samples according to the primer selected for equine influenza virus, subtype $\mathrm{H}_{3}$, and there have not been cross reactions with the samples of heterologous subtypes of equine influenza $A$ virus, Newcastle disease virus, and also a DNA band has been absent in a water sample.

On the next stage the experiments were conducted to evaluate sensitivity of the developed method. For that purpose the synthesized cDNA was serially diluted 10 -fold from $82 \mathrm{ng} / \mu \mathrm{l}$ to $0.082 \mathrm{fg}$. The results of the study are shown on Figure 3.

The sensitivity tests have shown that the developed PCR method allows detecting cDNA of EIV in concentration as low as $8.2 \mathrm{fg}$ in a sample.

So, the conducted research in development of RTPCR method for identification and typification of EIV, subtype $\mathrm{H}_{3}$, resulted in selection of optimal conditions for amplification reaction as well as of specific primers that allow generating PCR product sized at least $207 \mathrm{np}$.

The proposed RT-PCR method for equine influenza diagnosis is highly sensitive and specific to subtype $\mathrm{H}_{3}$ virus as well as reliable in detection of RNA of equine influenza virus of this subtype in biological samples without preliminary accumulation of the tested virus that is critically important in work with highly pathogenic strains. The method can be used for rapid identification of the equine influenza virus.

\section{CONCLUSION}

The performed research resulted in development of an effective version of c-ELISA for detection of antibodies to the equine influenza virus in blood sera of immune and convalescent animals.

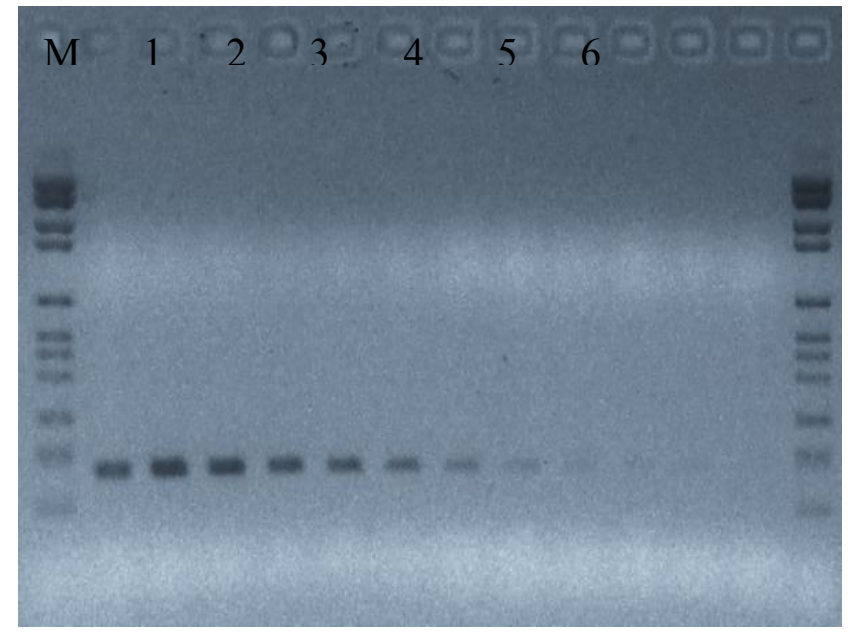

$\mathrm{M}$ - marker; $1-82 \mathrm{ng} ; 2-8.2 \mathrm{ng} ; 3-820 \mathrm{pg} ; 4-82 \mathrm{pg} ; 5$ $-8.2 \mathrm{pg} ; 6-0.82 \mathrm{pg} ; 7-0.082 \mathrm{pg} ; 8-8.2 \mathrm{fg} ; 9-0.82$ fg; $10-0.082 \mathrm{fg}$.

Fig 3 - Testing sensitivity of the PCR method in identification of EIV, subtype $\mathrm{H}_{3}$ 
For the first time in the Republic of Kazakhstan a test system based on RT-PCR is developed for diagnosis of equine influenza, subtype $\mathrm{H}_{3}$, which allows specific detection of the disease agent in any clinical material. In the course of monitoring surveys these test systems will allow evaluating spread of the equine influenza virus among animals on the territory of Kazakhstan.

\section{ACKNOWLEDGEMENT}

The authors are grateful to Yevgeniya Chebotar for translation of the article from Russian into English.

\section{REFERENCES}

Abduraimov, Ye.O., Zhugunisov, K.D. and Taranov, D.S (2011). Optimization of cultivation conditions for the equine influenza virus isolated in Zhambylskaya oblast (in Russian). Vestnik nauki KazATU S.Seifullina. 2 (69): 41-49.

Ballad, N.Ye. and Zorikhina, V.I. (1983). "ELISA Methods in Biology and Medicine" (collected papers). Moscow, 126-143.

Bryant, N.A. (2011). Antigenic and genetic variations in European and North American equine influenza virus strains (H3N8) isolated from 2008 to 2009. Veterinary Microbiology. 147(1-2): 19-27.

Chomel, J.J., Thouvenot, D. and Onno, M. (1989). Rapid diagnosis of influenza infection of NP antigen using an immunocapture ELISA test. J.Virol.Meth. 25:81-92.

Fouchier, R.A., Bestebroer, T.M., Herfst, S., Van Der Kemp, L., Rimmelzwaan, G.F. and Osterhaus, A.D. (2000). Detection of influenza A viruses from different species by PCR amplification of conserved sequences in the matrix gene. J.Clin.Microbiol. 38(11):4096-101.

Frimel, G. (1987). Immunological Methods. (In Russian) Moscow: "Meditsina", 472 p.

Gendon, Yu.Z. (1998). Influenza pandemic: is it possible to control it? (in Russian). Voprosy virusologii. 1:43-46.

Lowry, O.H., Rosebrough, N.I., Farr, A.L. and Randall, R.J. (1951). Protein measurement with the Folin Phenol Reagent. J.biol.Chem. 193:265-275.

OIE, Manual of Standards for Diagnostic Tests and Vaccines for Terrestrial Animals (mammals, birds and bees). - Vol.1-2.-5th ed. - Paris, 2004.

Petrov, R.V. and Khaitov, R.M. (1984). Raising hyperimmune sera to influenza virus $M$ protein. Voprosy virusologii. 3:271.

Sakoda, Y. and Kida, H. (2007). Genetic analyses of an H3N8 influenza virus isolate, causative strain of the outbreak of equine influenza at the Kanazawa racecourse in Japan in 2007. J.Vet.Med.Sci. 70:899906.
Sandybayev, N.T., Zholdybayeva, Ye.V. and Sultankulova, K.T. (2007). Influenza virus identification by PCR (in Russian). Biotekhnologiya. Teoriya I praktika. 3:90-94.

Selleck, P., Watson, J. and Batson, M. (2008). Influenza A virus: A blocking ELISA for the detection of antibodies to influenza A viruses in equine sera. Australian Animal Health Laboratory Quality Assurance Manual QA/Methods13 Distribution Updates Reviews 4 EIV FLU B-ELISA 94. 25 October 2008.

Sominina, A.A., Krivitskaya, V.Z. and Tretjakova, N.V. (2009). Detection of antibodies against influenza viruses $A(H 5 N 1)$ in sera of naturally infected and vaccinated humans and animals by microneutralization test. Methodological recommendations (in Russian). St.Petersburg, $13 \mathrm{p}$.

Thompson, W.W., Shay, D.K., Weintraub, E., Brammer, L., Cox, N., Anderson, L.J. and Fukuda, K. (2003). Mortality associated with influenza and respiratory syncytial virus in the United States. JAMA. 289(2):179-186.

Tsivanyuk, M.A., Lugovskaya, N.N. and Mudrak, N.S. (2006). Detection of antibodies against influenza $A$ virus in sera of domestic and wild birds. II International Veterinary Congress in Poultry Farming. Moscow, pp. 42-46.

Tsivanyuk, M.A., Lugovskaya, N.N. and Mudrak, N.S. (2007). Indirect ELISA for detection and quantification of antibodies against avian influenza virus while testing samples in one dilution. Veterinarnaya patologiya. 4(23):132-137.

Tudor, S.E. (2009). Development and evaluation of onestep Taq Man real-time reverse transcription-PCR assays targeting nucleoprotein, matrix, and hemagglutinin genes of equine influenza virus. J.Clin.Microbiol. 47:3907-3913.

Virmani, N., Singh, B.K, Gulati, B.R. and Kumar, S. (2008). Equine influenza outbreak in India. Vet.Rec. 163:607608.

Wilson, M.B. and Nakane, P.K. (1978). Recent development in the periodate method of conjugating horseradish peroxides (HRPO) to antibodies. Biomedical press. pp.215-244.

Yamanaka, T., Niwa, H., Tsujimura, K. and Kondo, T. (2008). Epidemic of equine influenza among vaccinated racehorses in Japan in 2007. J.Vet.Med.Sci. 70:623-625.

Zhemayeva, L.V., Kozlov, A.Yu., Yamnikova, S.S. and Kalnov, S.L. (2009). Development of a diagnostic test system on the basis of sandwich-ELISA for detection of avian influenza A virus (in Russian). Voprosy virusologii. 4:45-49. 